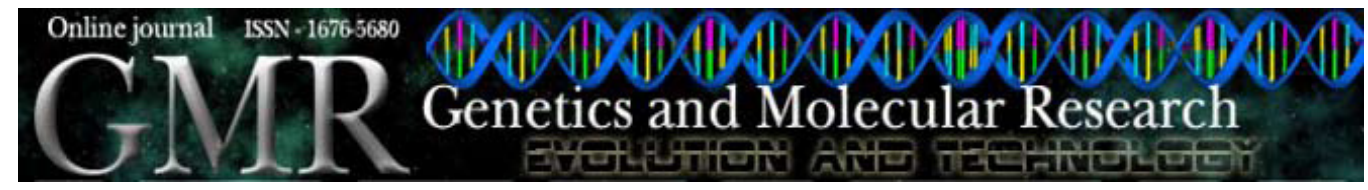

\title{
Comparative phylogenetic study of Stichotrichia (Alveolata: Ciliophora: Spirotrichea) based on 18S-rDNA sequences
}

\author{
T.S. Paiva ${ }^{1}$, B.N. Borges ${ }^{2}$, M.L. Harada ${ }^{2}$ and I.D. Silva-Neto ${ }^{1}$ \\ ${ }^{1}$ Departamento de Zoologia, Laboratório de Protistologia, \\ Instituto de Biologia, CCS, Universidade Federal do Rio de Janeiro, \\ Rio de Janeiro, RJ, Brasil \\ ${ }^{2}$ Laboratório de Biologia Molecular Francisco Mauro Salzano, \\ Instituto de Ciências Biológicas, Cidade Universitária Prof. José Silveira Netto, \\ Universidade Federal do Pará, Belém, PA, Brasil \\ Corresponding author: T.S. Paiva \\ E-mail: tpaiva@biologia.ufrj.br
}

Genet. Mol. Res. 8 (1): 223-246 (2009)

Received December 8, 2008

Accepted January 19, 2009

Published March 3, 2009

\begin{abstract}
Since molecular phylogenies of stichotrich ciliates started to be published, some remarkable contradictions to morphology-based classifications have been reported, such as the Convergent Evolution of Urostylids and Uroleptids (CEUU) hyphothesis, the Halteria paradox, the polyphyly of Oxytricha and of Stichotrichia. We hypothesized the internal phylogeny of 18S-rDNA from 53 morphological species of stichotrichs and their relationships with Hypotrichia and Oligotrichia using parsimony and neighbor-joining methods, including new data from Pseudouroleptus caudatus and Strongylidium pseudocrassum. Competing phylogenetic scenarios were compared using statistical tests, and the results suggest the reconsideration of both CEUU and the position of Halteria among flexible-body oxytrichids. The polyphyly of Oxytricha was not rejected and the monophyly of Stichotrichia was accepted based on parsimony analysis if Pseudoamphisiella is considered an external (discocephalid related) taxon.
\end{abstract}

Key words: CEUU; Halteria; Oxytricha; Strongylidium; Pseudouroleptus 


\section{INTRODUCTION}

During the last years, attempts to hypothesize the evolutionary relationships among the Stichotrichia (= Hypotricha in Berger, 2006) and closely related groups based on molecular data (e.g., Bernhard et al., 2001; Hewitt et al., 2003; Strüder-Kypke and Lynn, 2003; Foissner et al., 2004; Foissner and Stoeck, 2006) have given results that generally contradict other hypotheses and classification systems based on morphological data (e.g., de Puytorac et al., 1994; Berger and Foissner, 1997; Eigner, 1997, 1999, 2001; Lynn and Small, 2002; Lynn, 2003; Agatha, 2004; Foissner et al., 2007).

Molecular phylogenies have raised challenging inconsistencies with stichotrich systematics based on morphology. The most remarkable are: i) the placement of Halteria grandinella among the flexible-body oxytrichids (Bernhard et al., 2001; Strüder-Kypke and Lynn, 2003), referred to as the "Halteria paradox" (see Foissner et al., 2007); ii) the separation of Uroleptus from the urostylids (Croft et al., 2003; Hewitt et al., 2003; Foissner et al., 2004; Foissner and Stoeck, 2006, 2008), which led to the "Convergent Evolution of Urostylids and Uroleptids" (CEUU) hypothesis, and the polyphyly of the non-uroleptid urostylids, suggested in subsequent studies (Schmidt et al., 2007; Yi et al., 2008a,b); iii) the polyphyly of Oxytricha (Schmidt et al., 2007), and iv) the splitting of the Stichotrichia, which were polyphyletic in Yi et al. (2008b).

Furthermore, the position of Stichotrichia as a sister group of the Oligotrichia, often based on molecular phylogenies, is not entirely consensual with morphological analyses (Petz and Foissner, 1992; Eisler and Fleury, 1995; Agatha, 2004). Some of these suggest Hypotrichia (= Euplota in Berger, 2006) as the adelphotaxon of Stichotrichia (but see Foissner et al., 2007 as an exception) while others, less commonly, suggest the sister relationship of Hypotrichia and Oligotrichia (Snoeyenbos-West et al., 2004).

This study aims to contribute to the systematics of the Stichotrichia by hypothesizing its internal phylogeny and their relationship with Hypotrichia and Oligotrichia based on analyses of 18S-rDNA data and statistical comparisons of competing phylogenies. For the first time, sequences of Strongylidium pseudocrassum and Pseudouroleptus caudatus, species of contrasting taxonomy based on morphology (Borror, 1972; Tuffrau and Fleury, 1994; Eigner, 1997, 1999; Berger, 1999; Lynn and Small, 2002; Lynn, 2003; Paiva and Silva-Neto, 2007), were included and their systematic position was determined based on molecular data.

\section{MATERIALAND METHODS}

\section{Species identification and terminology}

Strongylidium pseudocrassum was obtained from samples of water containing bottom sediments from Cabiúnas Lagoon (Parque Nacional da Restinga de Jurubatiba, Macaé, RJ, Brazil, geographic coordinates: S $22^{\circ} 17^{\prime} 46.7^{\prime \prime} \mathrm{W} 41^{\circ} 41^{\prime} 32.3$ "). Pseudouroleptus caudatus was found in cultures of hydrated mud from the margins of the Alma River (Tocantins, Brazil, exact geographic coordinates unknown), kindly provided by a collaborator. These organisms were identified through standard microscopy techniques widely used to investigate ciliate morphology, including in vivo observations (Dragesco and Dragesco-Kernéis, 1986; Foissner, 1991), protargol-impregnation (Dieckmann, 1995) and scanning electron microscopy (Silva-Neto, 1994). The terminology adopted follows mainly the works of Eigner and Foissner (1994) and Berger $(1999,2006)$. In the text 
we refer to taxons of conflicting delimitation in the literature using vernacular names.

\section{DNA extraction, amplification and sequencing}

Approximately 30 cells of each species were picked from their respective cultures and transferred to staining jars, where sediment particles, small protists and other visible contaminants were carefully removed with micropipettes. The cells were washed several times with mineral water and left starving for about $2 \mathrm{~h}$. The excess water was removed until the cells became concentrated in a drop-sized pool in the middle of the stain jar. The cells were then fixed with two or three droplets of alcoholic Bouin mixture, prepared according to Dieckmann (1995), for about $5 \mathrm{~min}$, and then washed with distilled water until the medium became clear transparent. After this step, the fixed cells were collected with a micropipette and transferred to microtubes for DNA isolation.

The cells were treated with lysis buffer, homogeneity buffer and proteinase $\mathrm{K}(10 \mathrm{mg} / \mathrm{mL})$ at $55^{\circ} \mathrm{C}$ for $2 \mathrm{~h}$, followed by the phenol-chloroform protocol described in Sambrook et al. (1989). The DNA was eluted overnight in TE solution and then stored at $-20^{\circ} \mathrm{C}$.

For amplification of 18S-rDNA gene, primers were designed based on conserved regions found in sequences of Stichotrichia based on the literature (Table 1). Two independent polymerase chain reactions (PCRs) were run to amplify the gene, resulting in overlapped fragments, using the primers: Cil18SF 5' GTCATATGCTTGTCTCAAAGACTAAGCC 3' and Cill8SR 5' CGACTTCTCCTTCCTCTAAGTGATATGG 3' for the first segment, and Cil910 5' TTAGAGTGTTCCAGGCAGGC 3' and Cil2279 5' ACTTCGCTGCGTTCTTCATCG 3' for the second one. The conditions of each reaction were: $5 \mathrm{~min}$ at $94^{\circ} \mathrm{C}$ for initial denaturation, followed by 40 cycles of $94^{\circ} \mathrm{C}$ for $30 \mathrm{~s}, 57^{\circ} \mathrm{C}$ for $30 \mathrm{~s}$ and $72^{\circ} \mathrm{C}$ for $30 \mathrm{~s}$. The final extension was at $72^{\circ} \mathrm{C}$ for $5 \mathrm{~min}$. Amplified fragments were purified with the phenolic method (Sambrook et al., 1989) and sequenced by the dideoxyterminal method (Sanger et al., 1977) using the $A B I$ 377 (Applied Biosystems) automatic sequencer equipment using these primers and three internal ones for the second gene segment: Cil1239 5' CCGACTAGGGATCGGAGG 3', Cills61 5' GAGACCTTAGCCTACTAA 3' and Cill838 5' TTGGAATTATAGATCTTGAA 3'.

\section{Sequence alignment and optimization}

Initially, a data base containing 63 sequences of Stichotrichia (including those of $S$. pseudocrassum and P. caudatus) were aligned with 23 outgroup sequences (Heterotrichia, Hypotrichia, Licnophora and Phacodinium) through the "progressive approach of multiple sequence alignment" of Feng and Doolittle (1987) implemented in the Clustal X 1.81 computer software (Thompson et al., 1997). Penalties for gap-opening and -extension were adjusted to improve the average alignment quality score (Q-score), calculated with TuneClustalX (Hall, 2004). The resulting alignment was further refined and trimmed manually to mount a character matrix, using the BioEdit v7.0.5 software (Hall, 1999). The quality of the resulting matrix was then assessed by checking its degree of saturation with the DAMBE software (Xia and Xie, 2001). To minimize reconstruction artifacts such as long-branch attraction, which can be associated with signal noise caused by mutational saturation (Felsenstein, 1978; Philippe, 2000; Lartillot et al., 2007), one outgroup sequence was removed at a time, commencing from the most distant (Philippe and Laurent, 1998; Brinkmann et al., 2005), and the whole sequence alignment procedure was redone until the matrix was clean of saturation, reducing the outgroup assemblage to nine sequences (Table 1). 
T.S. Paiva et al.

Table 1. Sequences used in our study and their GenBank accession numbers.

\begin{tabular}{|c|c|}
\hline Species & Accession numbers \\
\hline Amphisiella magnigranulosa & AM412774 \\
\hline Anteholosticha manca & DQ503578 \\
\hline Anteholosticha multistylata & AJ277876 \\
\hline Apokeronopsis crassa & DQ359728 \\
\hline Aspidisca steini & AF305625 \\
\hline Blepharisma americanum & M97909 \\
\hline Certesia quadrinucleata & DQ059581 \\
\hline Codonellopsis americana & AY143571 \\
\hline Cyrtohymena citrina (1) & AF508755 \\
\hline Cyrtohymena citrina (2) & AY498653 \\
\hline Diaxonella pseudorubra polystylata & AF508760 \\
\hline Diaxonella trimarginata & DQ190950 \\
\hline Diophrys appendiculata & AY004773 \\
\hline Engelmanniella mobilis & AF508757 \\
\hline Eufolliculina uhligi & U47620 \\
\hline Euplotes aediculatus & M14590 \\
\hline Euplotes crassus & AJ310492 \\
\hline Euplotes eurystomus & AJ310491 \\
\hline Euplotes minuta & AJ310490 \\
\hline Favella panamensis & AY143572 \\
\hline Gastrostyla steinii & AF508758 \\
\hline Gonostomum namibiense & AY498655 \\
\hline Gonostomum strenuит & AJ310493 \\
\hline Halteria grandinella & AF 194410 \\
\hline Hemiurosoma terricola & AY498651 \\
\hline Holosticha diademata & DQ059583 \\
\hline Holosticha heterofoissneri & DQ059582 \\
\hline Laurentiella strenua & AJ310487 \\
\hline Licnophora macfarlandi & AF527758 \\
\hline Maristentor dinoferus & AY630405 \\
\hline Novistrombidium testaceum & AJ488910 \\
\hline Onychodromopsis flexilis (1) & AY498652 \\
\hline Onychodromopsis flexilis (2) & AM412764 \\
\hline Onychodromus grandis & AJ310486 \\
\hline Orthoamphisiella breviseries & AY498654 \\
\hline Oxytricha elegans & AM412767 \\
\hline Oxytrich a ferruginea & AF370027 \\
\hline Oxytricha granulifera (1) & AM412769 \\
\hline Oxytricha granulifera (2) & X53486 \\
\hline Oxytricha granulifera (3) & AM412772 \\
\hline Oxytricha granulifera (4) & AM412771 \\
\hline Oxytricha granulifera (5) & AF508762 \\
\hline Oxytricha lanceolata & AM412773 \\
\hline Oxytricha longa & AF508763 \\
\hline Oxytricha longigranulosa & AM412766 \\
\hline Oxytricha saltans & AF370028 \\
\hline Parabirojimia similis & DQ503584 \\
\hline Paraurostyla viridis & AF508766 \\
\hline Paraurostyla weissei (1) & AJ310485 \\
\hline Paraurostyla weissei (2) & AY294648 \\
\hline Pattersoniella vitiphila & AJ310495 \\
\hline Peritromus kahli & AJ537427 \\
\hline Phacodinium metchnikoffi & AJ277877 \\
\hline Plagiotoma lumbrici & AY547545 \\
\hline Pleurotricha lanceolata & AF508768 \\
\hline
\end{tabular}

Continued on next page

Genetics and Molecular Research 8 (1): 223-246 (2009)

CFUNPEC-RP www.funpecrp.com.br 


\begin{tabular}{|c|c|}
\hline Species & Accession numbers \\
\hline Prodiscocephalus borrori & DQ646880 \\
\hline Pseudoamphisiella alveolata & DQ503583 \\
\hline Pseudoamphisiella lacazei & DQ777743 \\
\hline Pseudokeronopsis carnea & AY881633 \\
\hline Pseudokeronopsis flava & AY881634 \\
\hline Pseudokeronopsis rubra & DQ640314 \\
\hline Pseudouroleptus caudatus & DQ910904 \\
\hline Pseudourostyla cristata & DQ019318 \\
\hline Pseudourostyla franzi & AM412765 \\
\hline Rigidothrix goiseri & DQ490236 \\
\hline Steinia sphagnicola & AJ310494 \\
\hline Stentor polymorphus & AF357144 \\
\hline Sterkiella histriomuscorum & AF508770 \\
\hline Sterkiella nova & AF508771 \\
\hline Strombidinopsis jeokjo & AJ628250 \\
\hline Strombidium inclinatum & AJ488911 \\
\hline Strombidium purpureum & U97112 \\
\hline Strongylidium pseudocrassum & DQ910903 \\
\hline Stylonychia lemnae & AJ310496 \\
\hline Stylonychia mytilus & AJ310499 \\
\hline Styxophrya quadricornuta & X53485 \\
\hline Tetmemena pustulata (1) & X03947 \\
\hline Tetmemena pustulata (2) & AF508775 \\
\hline Tintinnopsis fimbriata & AY 143560 \\
\hline Trachelostyla pediculiformis & DQ057346 \\
\hline Uroleptus gallina & AF164130 \\
\hline Uroleptus lepisma & AF508765 \\
\hline Uroleptus piscis & AF164131 \\
\hline Uronychia transfuga & AF260120 \\
\hline Urostyla grandis (1) & AF164129 \\
\hline Urostyla grandis (2) & AF508781 \\
\hline
\end{tabular}

Species marked in grey were excluded from the final nucleotide character matrix due to mutational saturation. Species initially assumed as outgroups are marked in bold.

\section{Phylogenetic analyses}

Our initial assumption of ingroup monophyly circumscribed the Stichotrichia sensu Berger (2006). The outgroups Hypotrichia and Oligotrichia correspond to euplotids (including the discocephalid Prodiscocephalus) and oligotrichs + choreotrichs, respectively.

The character matrix was analyzed with maximum parsimony (MP) and neighborjoining (NJ) methods using the PAUP* 4b10 software (Swofford, 2003). Alignment gaps were treated as a "fifth base" to preserve their information in MP analyses; uncertain bases were coded as missing data ("?" in PAUP*). According to Giribet and Wheeler (1999), NJ methods are unable to handle indel information in their calculations, so gaps were treated as "missing data" in these analyses. The sequences of Hypotrichia and Oligotrichia were analyzed simultaneously with the Stichotrichia. Two different root placements were attempted a posteriori: rooting according to the outgroup position (Nixon and Carpenter, 1993) and midpoint rooting (Farris, 1972). 
Optimization of character transformations followed the accelerated transformation (ACCTRAN) criterion. Inspection of character transformations over trees was based on PAUP* output log files containing apomorphy and character state change lists. The Mesquite 2.01 software (Maddison and Maddison, 2007) was used to trace the changes of the morphological character "presence of midventral complex" over trees, using parsimony criterion. Trees were visualized and edited for publishing on the MEGA 4 software (Tamura et al., 2007). The descriptive statistics and the Mann-Whitney test in Table 4 were calculated with the GraphPad Prism 4 software (Motulsky, 1999). In the text, we refer to the dendrograms generated by MP as "cladograms", and by NJ as "NJ trees".

\section{Maximum parsimony}

Initially, fundamental most parsimonious cladograms (FMPC) were obtained from an equal-weighted character matrix, through the parsimony ratchet strategy (Nixon, 1999) implemented in PAUP*, using a command block wrote by the accessory PaupRat program (Sikes and Lewis, 2001), which was adjusted to "tree bisection and reconnection" (TBR) branchswapping algorithm and 200 ratchet iterations. Independent runs were conducted until the total number of FMPC stabilized. Successive weighting (Farris, 1969) was applied by re-weighting the characters according to their maximum rescaled consistency index in the FMPCs, and a heuristic search (iteration) conducted using TBR with 300 replicates of random sequence addition. This procedure was repeated until the character weights stabilized for two consecutive iterations (Kitching et al., 1998). Character weights were scaled from 0 to 1 . Spuriously resolved branches were collapsed to polytomies whenever present.

\section{Neighbor-joining}

Prior to the analysis, a nucleotide substitution model (see Li, 1997; Schneider, 2007) was chosen through the "minimum theoretical information criterion" (Akaike, 1974; Bos and Posada, 2005) using the MODELTEST 3.7 software (Posada and Crandall, 1998). The NJ analysis was then performed using the BioNJ algorithm, which according to Gascuel (1997), produces trees with topologies more accurate than those from conventional NJ (Saitou and Nei, 1987). Likelihood was used as a criterion to calculate a pairwise distance matrix based on which phylogenetic tree was built, considering the substitution model parameters selected. Branch length estimates and tree-score calculation by minimum-evolution function were conducted with the default settings of PAUP* (Schneider, 2007).

\section{Nodes reliability assess}

For both MP and NJ optimal trees, the reliability of the internal nodes was assessed through 1000 bootstrap pseudo-replicates generated by PAUP*. Under the parsimony criterion, only parsimony-informative characters (Carpenter, 1996) were analyzed by heuristic tree search with TBR and simple sequence addition. Characters were sampled with equal probability, but their final weights were considered. The BioNJ algorithm was employed under the distance criterion. Support values inferior to $50 \%$ were not assigned to the optimal trees (Figures 1,2). Tree metrics for bootstrap analyses were based on $50 \%$ majority rule consensus trees (Table 2). 


\begin{tabular}{|c|c|c|c|c|c|c|c|c|}
\hline Trees & $\mathrm{CI}$ & $\mathrm{HI}$ & $\mathrm{RC}$ & RI & $\mathrm{TL}(\mathrm{E})$ & $\mathrm{TL}(\mathrm{S})$ & ME score & $-\ln \mathrm{L}$ \\
\hline FMPC & 0.427 & 0.578 & 0.252 & 0.596 & 2458 & - & - & - \\
\hline SW iteration 1 & 0.685 & 0.315 & 0.486 & 0.710 & 2460 & 677.50548 & - & - \\
\hline MPC & 0.686 & 0.314 & 0.489 & 0.712 & 2460 & 675.89890 & - & - \\
\hline MP bootstrap consensus tree & 0.678 & 0.322 & 0.475 & 0.700 & 2520 & 684.50824 & - & - \\
\hline $\mathrm{NJ}$ tree & - & - & - & - & - & - & 1.68867 & 13896.06912 \\
\hline $\mathrm{NJ}$ bootstrap consensus tree & - & - & - & - & - & - & 1.70518 & 13977.92946 \\
\hline
\end{tabular}

\section{Test of hypotheses}

Unrooted trees with topological constraints were built using parsimony (heuristic search with TBR and 300 random sequence addition replicates) and distance (BioNJ, with the same parameters used to obtain the optimal tree) criteria using PAUP*. Each constraint corresponded to a different scenario enforced to obtain trees that contradict the CEUU hypothesis (I-IV), force the monophyly of the urostylids (V-VIII), the branching of Halteria grandinella among the Oligotrichia (IX), the monophyly of Oxytricha (X), and the monophyly of Stichotrichia (XI-XIII). The topological constraints are given in Table 3.

\begin{tabular}{|c|c|c|c|c|c|}
\hline Scenarios & Constrained topologies & SH & WSH & Templeton & WS \\
\hline I & Rigidothrix goiseri + Uroleptus spp & 0.82913 & 0.621 & 0.0459 & 0.1338 \\
\hline II & Rigidothrix goiseri + Uroleptus spp + Core urostylids & 0.78676 & 0.522 & 0.1492 & 0.1000 \\
\hline III & Uroleptus spp + Core urostylids & 0.41369 & 0.108 & 0.0422 & 0.1078 \\
\hline IV & Pattersoniella vitiphila + Rigidothrix goiseri + Uroleptus spp & 0.00015 & $<0.0001$ & $<0.0001$ & $<0.0001$ \\
\hline V & $\begin{array}{l}\text { Core urostylids }+ \text { Holosticha spp Parabirojimia similis }+ \\
\text { Pseudoamphisiella spp }\end{array}$ & 0.01301 & $<0.0001$ & $<0.0001$ & $<0.0001$ \\
\hline VI & $\begin{array}{l}\text { Core urostylids }+ \text { Holosticha } \text { spp Parabirojimia similis }+ \\
\text { Pseudoamphisiella } \mathrm{spp}+\text { Uroleptus } \mathrm{spp}\end{array}$ & 0.00606 & $<0.0001$ & $<0.0001$ & $<0.0001$ \\
\hline VII & $\begin{array}{l}\text { Core urostylids }+ \text { Holosticha } \mathrm{spp} \text { Parabirojimia similis }+ \\
\text { Pseudoamphisiella spp }+ \text { Rigidothrix goiseri }+ \text { Uroleptus } \mathrm{spp}\end{array}$ & 0.00052 & $<0.0001$ & $<0.0001$ & $<0.0001$ \\
\hline VIII & $\begin{array}{l}\text { Core urostylids }+ \text { Holosticha } \mathrm{spp} \text { Parabirojimia similis }+ \\
\text { Pattersoniella vitiphila }+ \text { Pseudoamphisiella } \mathrm{spp}+ \\
\text { Rigidothrix goiseri }+ \text { Uroleptus } \mathrm{spp}\end{array}$ & $<0.0001$ & $<0.0001$ & $<0.0001$ & $<0.0001$ \\
\hline IX & Oxytricha spp & $<0.0001$ & $<0.0001$ & $<0.0001$ & $<0.0001$ \\
\hline $\mathrm{X}$ & Halteria grandinella + Oligotrichia & 0.38575 & 0.119 & 0.0255 & 0.0059 \\
\hline XI & Stichotrichia sensu Berger (2006) & 0.16105 & 0.003 & $<0.0001$ & $<0.0001$ \\
\hline XII & Core Stichotrichia + Holosticha $\mathrm{spp}+$ Oxytricha saltans & 0.98290 & 0.939 & - & - \\
\hline XIII & Core Stichotrichia + Pseudoamphisiella spp & 0.57696 & 0.056 & 0.0003 & 0.0018 \\
\hline
\end{tabular}

Values for rejection of null hypotheses are marked in gray. $\mathrm{SH}=$ Shimodaira-Hasegawa; WS = winning sites; WSH $=$ weighted Shimodaira-Hasegawa. $\alpha=0.01$.

To examine the support of the data for such competing hypotheses, we tested whether shortest trees (unconstrained) differed significantly from the constrained ones, comparing them in likelihood and parsimony frameworks, based on the criteria with which they were built, and considering a conservative significance level $(\alpha)$ of 0.01 . The NJ trees were compared through 
the "Shimodaira-Hasegawa" (SH) test implementation in PAUP*, with the SH distribution generated with 10,000 bootstrap pseudo-replicates by the "resampled estimated log-likelihood" method (Kishino et al., 1990), and the "weighted Shimodaira-Hasegawa" (WSH) test (Shimodaira, 1993, 1998; Shimodaira and Hasegawa, 1999; Buckley et al., 2001) using the CONSEL software package (Shimodaira and Hasegawa, 2001) with 1,000,000 multiscale bootstrap pseudo-replicates (Shimodaira, 2005). Cladograms were compared using two sitewise tests: the "Wilcoxon signed-ranks" (Templeton, 1983) and the "winning sites" test (WS) (see Prager and Wilson, 1988), both ran in PAUP*, following Schneider (2007), and considering characters' final weights.

\section{RESULTS AND DISCUSSION}

\section{Sequences and alignment}

The 18S-rDNA sequences of $P$. caudatus and S. pseudocrassum had 1717 nucleotides and were deposited in GenBank (accession codes in Table 1). The final character matrix contained 72 sequences of 63 different morphological species, which after they were trimmed, had 1679 characters, of which 1071 were constant, 204 were variable but parsimony-uninformative, and 404 parsimony-informative. Gap opening and extension penalties were set to 30.0 and 2.00, respectively, resulting in an optimum Q-score of 90.9506.

\section{Maximum parsimony}

After four parsimony ratchet runs, the number of FMPC stabilized in 12 cladograms (not shown) each measuring 2458 steps. Character weights stabilized at the second successive iteration, producing a single most parsimonious cladogram (MPC), which was not among the 12 FMPCs and was two steps longer than those, when measured based on an equal-weighted matrix (Figure 1, Table 2). The resulting matrix had 1338 characters with weights equal to 1 , and 341 characters that received other weights. As a favorable sideeffect (but not an obligatory one), the process reduced the number of MPCs to one fully resolved topology (Kitching et al., 1998). The initially equal-weighted matrix produced cladograms with large amounts of homoplasy, expressed by the ensemble homoplasy index in FMPCs (igual to 0.578). Application of a posteriori character weighting resulted in a more consistent tree (Farris, 1969, 1989a; Kitching et al., 1998), which had a homoplasy index igual to 0.314. In this context, we agree with Platnick et al. $(1991,1996)$, Goloboff (1993, 1997) and Goloboff et al. (2008), who defend that parsimony analyses require weighting to achieve self-consistent results. For a contrary view, see Turner and Zandee (1995), Källersjö et al. (1999), and Kluge (1997a,b; 2005).

\section{Neighbor-joining}

The 18S-rDNA data were best fit to the "General Time Reversible" (GTR) nucleotide substitution model (Rodriguez et al., 1990), with 44.99\% invariable sites (I) and gamma distribution $(\gamma)$ of rate equivalent to 0.1542 (GTR $+\mathrm{I}+\mathrm{G}$; negative $\log$ likelihood $[-\mathrm{lnL}]=16678.7188)$. This model assumed a symmetric substitution rate (R) matrix with six possible transformations (Hillis et al., 


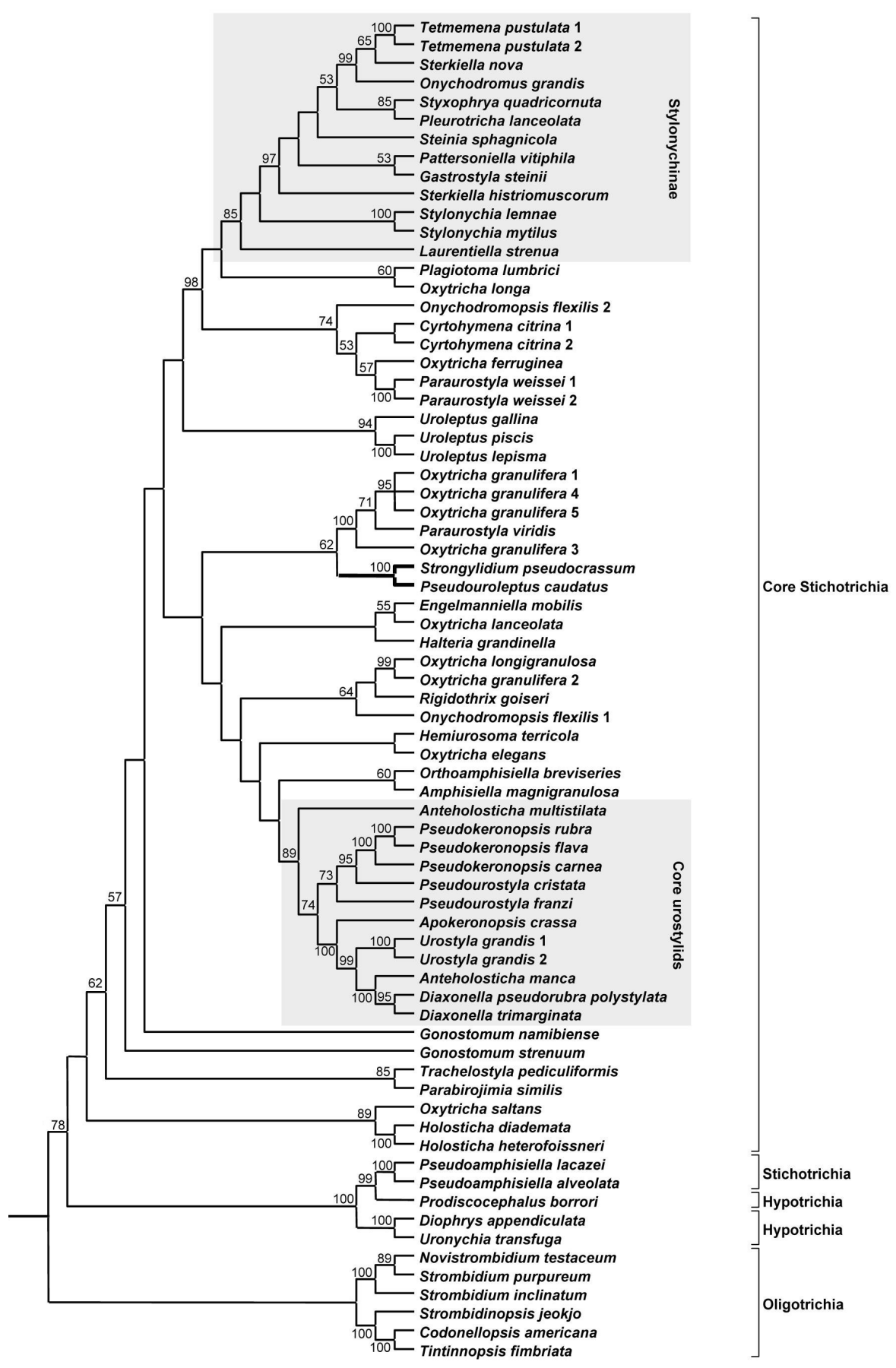

Figure 1. Single most parsimonious cladogram built using parsimony ratchet search strategy and successive weighting. Branches with new sequences are marked in bold. Values associated with nodes correspond to bootstrap support in $\%$. 
1996; Li, 1997) (a, b, c, d, e, f), which were: $\mathrm{R}(\mathrm{a})[\mathrm{A}-\mathrm{C}]=1.5507 ; \mathrm{R}(\mathrm{b})[\mathrm{A}-\mathrm{G}]=3.2390 ; \mathrm{R}(\mathrm{c})[\mathrm{A}-\mathrm{T}]$ $=1.5154 ; \mathrm{R}(\mathrm{d})[\mathrm{C}-\mathrm{G}]=1.1415 ; \mathrm{R}(\mathrm{e})[\mathrm{C}-\mathrm{T}]=5.5128 ; \mathrm{R}(\mathrm{f})[\mathrm{G}-\mathrm{T}]=1.0000$. Nucleotide frequencies of $25.43,19.22,26.21$, and $29.14 \%$ were found for bases A, C, G, T, respectively. The resulting tree (Figure 2, Table 2) had a minimum evolution score of 1.68867 and $-\operatorname{lnL}=13896.06912$.

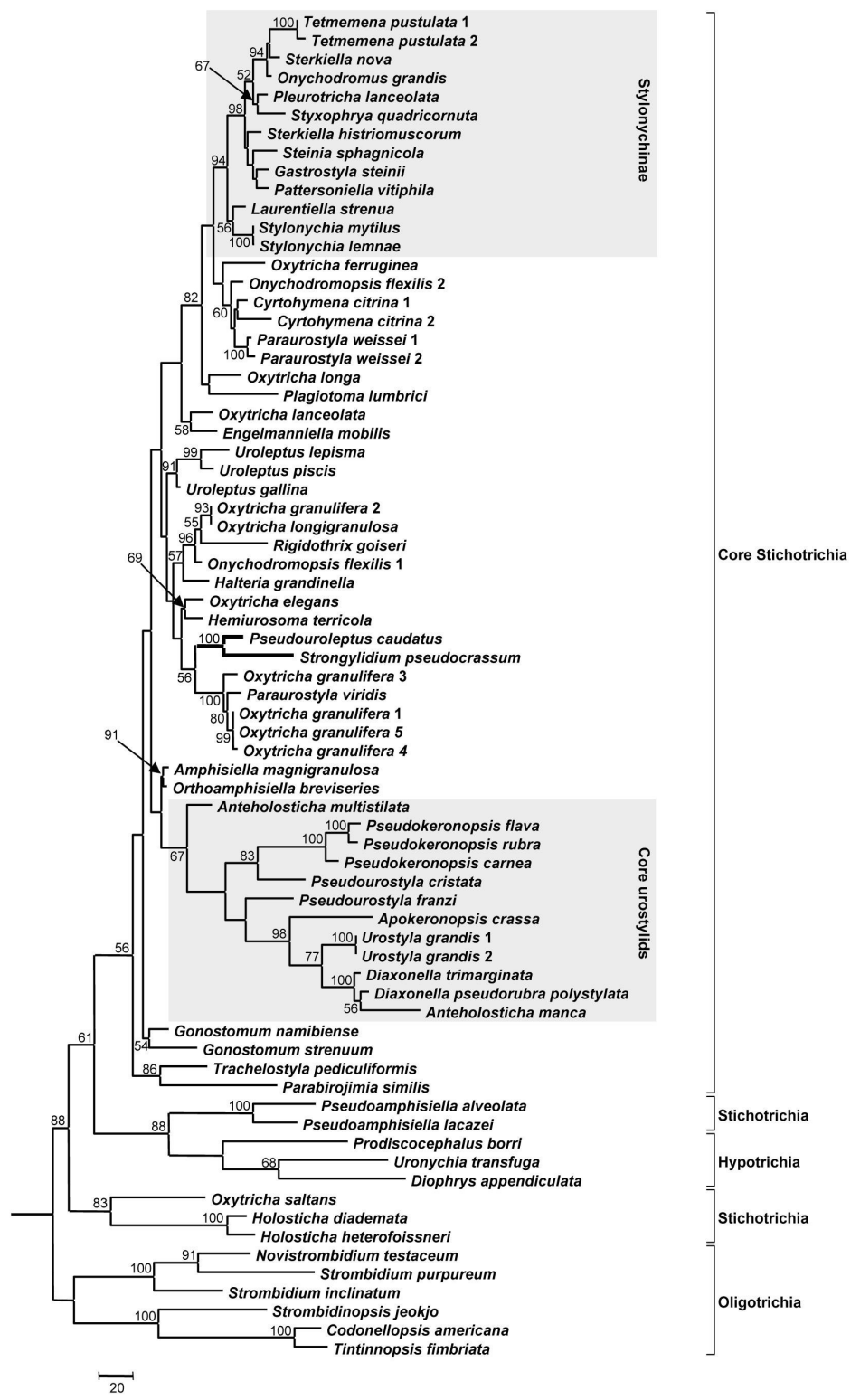

Figure 2. Neighbor-joining tree built using the BioNJ algorithm and the GTR $+\mathrm{I}+\mathrm{G}$ model of nucleotide substitution. Branches with new sequences are marked in bold. Values associated with nodes correspond to bootstrap support in $\%$. Scale bar: substitutions per site. 


\section{Root placement}

In both unrooted trees, monophyly of the Stichotrichia was not supported. In the MPC, Pseudoamphisiella spp formed a clade with Prodiscocephalus borrori, standing between the core Stichotrichia + Oligotrichia and the Hypotrichia. Yi et al. (2008b) found similar results regarding the placement of Pseudoamphisiella spp and Prodiscocephalus, which grouped with $64 \%$ bootstrap support ( $99 \%$ in our MPC). In the NJ tree, however, P. borrori branched from the base of Hypotrichia independently from Pseudoamphisiella spp, with $<50 \%$ bootstrap support. Additionally, the group formed by Holosticha spp + Oxytricha saltans remained outside of the core Stichotrichia, but with bootstrap $<50 \%$.

The relative position of the outgroup taxons thus did not corroborate the initial premise of a monophyletic ingroup, therefore, rooting the trees according to outgroup comparison criterion produced an arbitrary choice of which group would be the most distant from the stichotrichs.

Considering the euplotid hypotrichs as an outgroup leads to the suggestion of the union of Stichotrichia and Oligotrichia, perhaps due to the presence of the perilemma (Foissner et al., 2007). On the other hand, rooting with the oligotrichs as an outgroup would suggest the common ancestrality of Hypotrichia and Stichotrichia, morphologically supported by the presence of cirri (Petz and Foissner, 1992; Agatha, 2004). Either way, we agree with Berger (2006) that more data are needed to determine the relationships among these three groups. Moreover, if the root is placed following the relationships recovered in molecular studies, then it should be placed at the point of divergence between Diophrys appendiculata + Uronychia transfuga and the remaining taxons. However, one must be aware of the possibility that artifacts caused by mutational saturation could have misled the understanding of the relationship of the Stichotrichia with more distant groups (including hypotrichs, oligotrichs, and basal spirotrichs) in those studies. Therefore, we used another root placement criterion, viz. midpoint rooting (Farris, 1972; Felsenstein, 1978; Qiu et al., 2001; Sanderson and Shaffer, 2002), which as shown by Hess and de Moraes Russo (2007), can be very effective in such cases where the "real" outgroup is not clearly defined. This method does not require external assumptions based on previous analyses, avoiding arbitrary outgroup choice by placing the root at the midpoint between the two most divergent operational taxonomic units (Swofford et al., 1996; Nei and Kumar, 2000).

Accordingly, the root was placed at the branching point from the Oligotrichia to the remaining taxons, in agreement with morphological studies (Petz and Foissner, 1992; Eisler and Fleury, 1995; Agatha, 2004).

\section{Tree topologies and nodal support}

Both the MPC and NJ tree were almost fully resolved (with the exception of Oxytricha granulifera trichotomy), but there was considerable disagreement at family and order levels. Strict consensus of both topologies (Figure 3) did not depict a monophyletic Stichotrichia due to the aforementioned position of Pseudoamphisiella spp and because the Holosticha spp + Oxytricha saltans group was included in the core Stichotrichia only in the MPC. The position of Holosticha outside a major lineage of stichotrichs was already described by Schmidt et al. (2007); however, they did not include euplotid hypotrichs in their analyses, so the branching 
pattern was slightly different. Additionally, Oxytricha saltans grouped with Gonostomum spp in their study, but with $<50 \%$ bootstrap support.

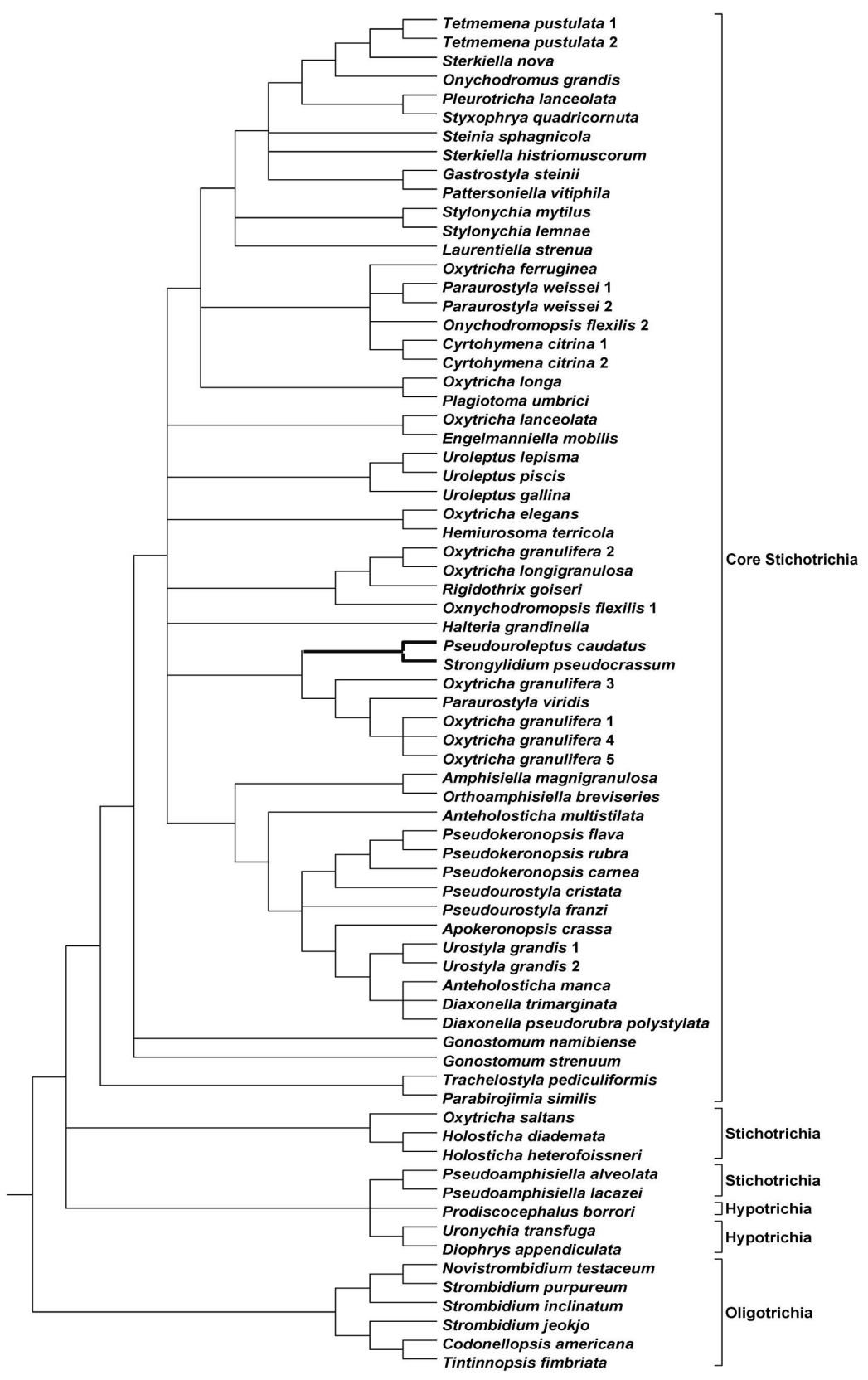

Figure 3. Strict consensus topology of the optimal cladogram and neighbor-joining tree. Branches with new sequences are marked in bold. 
The core Stichotrichia was composed of the Trachelostyla pediculiformis + Parabirojimia similis group, also hypothesized by Gong et al. (2007); Gonostomum spp (which formed a monophylum in the NJ tree, with bootstrap support of only 54\%) plus a larger group that consisted of a dichotomous subset of the stichotrich species. Inasmuch as the phylogenetic hypotheses generated according to parsimony or distance criteria were not entirely consensual, two major well-resolved groups were displayed in opposite sides of this dichotomy: the Stylonychinae Berger and Foissner, 1997, and the core urostylids (Figures 1, 2).

The rigid-body subfamily Stylonychinae was proposed by Berger and Foissner (1997) based on cladistic analyses of morphological traits from typical oxytrichids. This group is often recovered in molecular phylogenies (e.g., Bernhard et al., 2001; Hewitt et al., 2003; Foissner et al., 2004; Schmidt et al., 2007; Shao et al., 2007; Yi et al., 2008a,b) and so they were in both our trees, however, with discrepant placement of Steinia sphagnicola and Sterkiella histriomuscorum. Nevertheless, stylonychine external affinities did not follow the same pattern in both trees.

Closely related to the Stylonychinae, but with different placements, were the Oxytricha longa + Plagiotoma lumbrici group and the cyrtohymenids. The former is a notable odd pair, since morphologically Plagiotoma is assumed to be distantly related to a typical oxytrichid due to its "holotrichous" ciliature pattern. Affa'a et al. (2004) speculated that this organism could be a highly apomorphic stichotrich adapted to endosymbiotic life in the intestine of annelid worms. Among the cyrtohymenids, Cyrtohymena citrina was found to be paraphyletic by Foissner et al. (2004) and Foissner and Stoeck (2008). In our trees, both sequences of this species formed a monophylum, but with $<50 \%$ bootstrap support, compatible with the study by Foissner and Stoeck (2006). The close relationship of Cyrtohymena, the Onychodromopsis flexilis population from Salzburg, Oxytricha ferruginea [Cyrtohymena ferruginea sensu Foissner (1989)] and Paraurostyla weissei was also similar to what was reported in a previous study (Schmidt et al., 2007).

Engelmanniella mobilis and Oxytricha lanceolata consistently formed a monophylum in our trees, agreeing with the Bayesian tree in Schmidt et al. (2007), but with bootstrap values close to $50 \%$ and branching at highly discrepant points. In the MPC, they formed a clade with Halteria grandinella, which in both trees branched off from different, but nearby points in relation to the monophyletic group formed by the Antartic population of Onychodromopsis flexilis, Oxytricha granulifera 2 and Oxytricha longigranulosa (both equal after aligned and trimmed), and Rigidothrix goiseri. These sequences formed monophyla in both analyses, which is compatible with the findings from other studies (Foissner and Stoeck, 2006, 2008; Schmidt et al., 2007).

The new sequences of $S$. pseudocrassum and $P$. caudatus formed a monophyletic group in both trees with high bootstrap support. Their $18 \mathrm{~S}$ sequences shared $96.2 \%$ similarity, confirming that these two organisms are closely related (Paiva and Silva-Neto, 2007). In our analyses, the Strongylidium + Pseudouroleptus group was closely related to the remaining Oxytricha granulifera populations and Paraurostyla viridis. According to Berger (2006), the latter may be a misidentified species, because of its ambiguous phylogenetic placement (Kelminson et al., 2002; Croft et al., 2003; Hewitt et al., 2003) and given that no morphological data were provided as evidence of correct identification. We decided to include it in our study to determine how it would be placed when analyzed in a broader taxon sample context than it originally was. 
We found that Paraurostyla viridis grouped among Oxytricha granulifera sequences, forming a monophylum with Oxytricha granulifera 1,4 and 5 (the sequences $O$. granulifera 1 and 5 were found to be equal after being aligned and trimmed), supported by bootstrap values of 71 and $80 \%$ in MPC and NJ tree, respectively. This result is compatible with the findings of Hewitt et al. (2003) and may indicate a misidentification, this being a strain of Paraurostyla viridis or possibly a sample from another population of Oxytricha granulifera. Moreover, the group formed by Oxytricha elegans and Hemiurosoma terricola, although recovered in both trees, has affinities that are not equally established.

The kinships of Uroleptus were not consensually hypothesized, even though the genus was monophyletic in both trees. In the MPC it was the sister taxon of the group formed by the cyrtohymenids, Oxytricha longa + Plagiotoma lumbrici and the Stylonychinae, a pattern that is commonly reported (Foissner and Stoeck, 2006, 2008; Schmidt et al., 2007; Gong et al., 2007). In the NJ tree, however, Uroleptus branched off the base of the group that contained Rigidothrix goiseri, a species with a similar cirral pattern, but that has a rigid body and lacks cortical granules (Foissner and Stoeck, 2006). This, however, puts Uroleptus in a phylogenetic position that is more compatible with that found in Foissner et al. (2004).

Finally, a well-resolved taxon supported by the highest bootstrap values within the core Stichotrichia and recovered in both analyses was formed by Amphisiella magnigranulosa + Orthoamphisiella breviseries, confirming the polyphyly of the amphisiellids (Gong et al., 2007; Schmidt et al., 2007), plus the core urostylids. The latter displayed Pseudokeronopsis as a monophylum (Shao et al., 2007; Schmidt et al., 2007; Yi et al., 2008a,b) and the polyphyly of Anteholosticha Berger, 2003, which was already supposed by Berger $(2003,2006)$ because the genus was assembled with a combination of morphological plesiomorphies.

Additionally, the position of Pseudourostyla franzi was not consensually defined, inasmuch as it grouped with Pseudokeronopsis spp, with 73\% bootstrap support in the MPC. The two sequences of Urostyla grandis were found to be equal after aligned and trimmed, and grouped consistently with Diaxonella spp + Anteholosticha manca in both trees.

Among the 404 parsimony-informative characters in our matrix, 345 had a retention index (RI) of $>0$; therefore, they were retained as synapomorphies (Farris, 1989b). Of these, 63 had RI $=1.000,38$ had $\mathrm{RI} \geq 0.750$ and $\leq 0.957,107$ had $\mathrm{RI} \geq 0.556$ and $\leq 0.743$, 98 had RI $\geq 0.364$ and $\leq 0.545$, and 39 had $R I \geq 0.143$ and $\leq 0.348$. Thus, more than half of the synapomorphies that united the groups in Figure 1 were potentially homoplastic. According to Kitching et al. (1998), groups that are corroborated by small percentages of informative characters tend to exhibit low bootstrap support because they are less frequently recovered during resamplings, especially if they are united by homoplastic characters.

We observed 17 nodes with bootstrap support $<50 \%$ in the MPC and 20 in the NJ tree. In the MPC the nodes with support $<50$ and $\geq 50 \%$ were corroborated on average by 4 and 18 characters, respectively. When the distribution of characters was plotted on the NJ tree, the former value changed to 7 characters. We also found that the differences in the arithmetic means of the number of characters associated with nodes with $<50$ and $\geq 50 \%$ support did not differ significantly between the MPC and the NJ tree (Table 4). Albeit using different premises, both analyses exhibited similar trends in nodal support, since in both trees, the nodes with support of $\geq 50 \%$ tended to be away from the tree spine and close to the terminals. Similar trends were noticed in other 18S phylogenies of unicellular eukaryotic organisms (e.g., Deane et al., 2002; Cavalier-Smith and Chao, 2003) and of land plants (Soltis et al., 1999). 


\begin{tabular}{|c|c|c|c|c|c|c|c|c|c|c|}
\hline Groups* & Mean & M & SD & Min & Max & $\mathrm{N}$ & Groups & MP bs $<50$ & $\mathrm{MP}$ bs $\geq 50$ & $\mathrm{NJ}$ bs $<50$ \\
\hline MP bs $<50$ & 4.29 & 4 & 3.24 & 1 & 13 & 17 & MP bs $<50$ & & & \\
\hline $\mathrm{MP}$ bs $\geq 50$ & 18.35 & 15 & 17.93 & 1 & 87 & 51 & $\mathrm{MP}$ bs $\geq 50$ & $\begin{array}{c}\mathrm{U}=131.5 \\
\mathrm{P}<0.0001\end{array}$ & & \\
\hline $\mathrm{NJ}$ bs $<50$ & 7.15 & 5 & 7.68 & 2 & 32 & 20 & $\mathrm{NJ}$ bs $<50$ & $\begin{aligned} \mathrm{U} & =125.0 \\
\mathrm{P} & =0.1742\end{aligned}$ & $\begin{aligned} U & =244.0 \\
P & =0.0007\end{aligned}$ & \\
\hline $\mathrm{NJ}$ bs $\geq 50$ & 17.77 & 14 & 17.64 & 1 & 83 & 48 & $\mathrm{NJ}$ bs $\geq 50$ & $\begin{array}{l}\mathrm{U}=135.0 \\
\mathrm{P}<0.0001\end{array}$ & $\begin{aligned} \mathrm{U} & =1177.0 \\
\mathrm{P} & =0.7447\end{aligned}$ & $\begin{aligned} \mathrm{U} & =245.0 \\
\mathrm{P} & =0.0016\end{aligned}$ \\
\hline
\end{tabular}

Mean = arithmetic mean; $\mathrm{M}=$ median; $\mathrm{SD}=$ standard deviation; $\mathrm{Max}=$ maximum number of character transformations; $\mathrm{Min}=$ minimum number of character transformations; $\mathrm{N}=$ number of nodes; $\mathrm{U}=$ Mann-Whitney test statistics. Values for rejection of null hypothesis are marked in gray. $\alpha=0.01$. *The node corresponding to the monophyly of the outgroup was not considered.

\section{The CEUU hypothesis and the polyphyly of urostylids}

After molecular phylogenetic studies suggested that the traditional urostylids (Borror, 1979; Lynn and Small, 2002; Lynn, 2003) were not a monophyletic assemblage because of the position of Uroleptus species (Croft et al., 2003; Hewitt et al., 2003), Foissner et al. (2004) conceived the CEUU hypothesis. It was proposed that Uroleptus is more closely related to the typical oxytrichids than to urostylids, and that its midventral complex had secondarily evolved (Foissner et al., 2004; Berger, 2006). The original CEUU was then modified after the discovery of Rigidothrix goiseri by Foissner and Stoeck (2006), a peculiar stichotrich with an uroleptid ciliature coexisting with typical stylonychine features (viz. a conspicuously rigid body, dorsal dikinetids encaged in fusiform structures, wide triangular peristome, and absence of cortical granules); but according to molecular phylogeny they belong to a lineage of typical flexible-body oxytrichids.

More recently, the discovery by Foissner and Stoeck (2008) of yet another stichotrich with phylogenetic affinities to the cyrtohymenids, Neokeronopsis (Afrokeronopsis) aurea (not included in our study), but possessing morphologic traits similar to Pattersoniella vitiphila (a stylonychine that has a midventral complex), expanded the complexity of the morphological foundation necessary to explain the CEUU, which was already considered weak when first proposed (Foissner et al., 2004). Accordingly, Foissner and Stoeck (2008) proposed that the midventral complex evolved independently in at least four lineages, viz. urostilids, uroleptids, rigidothrichids, and neokeronopsids (which includes Pattersoniella). Moreover, as aforementioned, other phylogenetic analyses decomposed the non-uroleptid urostylids into a polyphyletic group (Schmidt et al., 2007; Yi et al., 2008b).

If the presence/absence of midventral complex is traced on our optimal trees (not shown), then its independent rise in Uroleptus, Rigidothrix, Pattersoniella, and at least the core urostylid lineages is an acceptable hypothesis to explain its distribution in terminal taxons. However, the statistical tests that we used to compare the optimal trees with trees that were built with topological constraints failed to reject the null hypothesis in scenarios I-III (Table 3), meaning that the $18 \mathrm{~S}$ data alone do not yield sufficient resolution to generate a phylogenetic pattern robust enough to unambiguously support the construction of hypotheses 
on the evolution of Rigidothrix and Uroleptus, as well as their relation to other urostylids. Nevertheless, not only the report kinships of Uroleptus but also those of other "rogue" stichotrich groups vary in different studies, according to which gene data and reconstruction method are used, resulting sometimes in little resolved consensus trees (e.g., Snoeyenbos-West et al., 2002; Hewitt et al., 2003; Dalby and Prescott, 2004; Schmidt et al., 2007).

The CEUU hypothesis also finds support in a multi-gene tree from Hewitt et al. (2003, p. 264), which is roughly similar to the tree in Berger (2006, p. 33), from where uroleptids branched immediately after the urostylids. A tree in Foissner and Stoeck $(2008$, p. 31) shows a similar, but improved scenario with the addition of the rigidothrichids and neokeronopsids.

If the presence/absence of the midventral complex is traced over this tree, then the trend that minimizes the number of steps required to explain the distribution of this character on terminals is the presence of the midventral complex as a plesiomorphy (Figure 4), instead of multiple convergent evolution. Therefore, its absence in the remaining taxons (of the Dorsomarginalia Berger, 2006) was supposedly due to decreases in the number of ventral cirral primordia and/or increases in the number of cirri generated by each primordium.

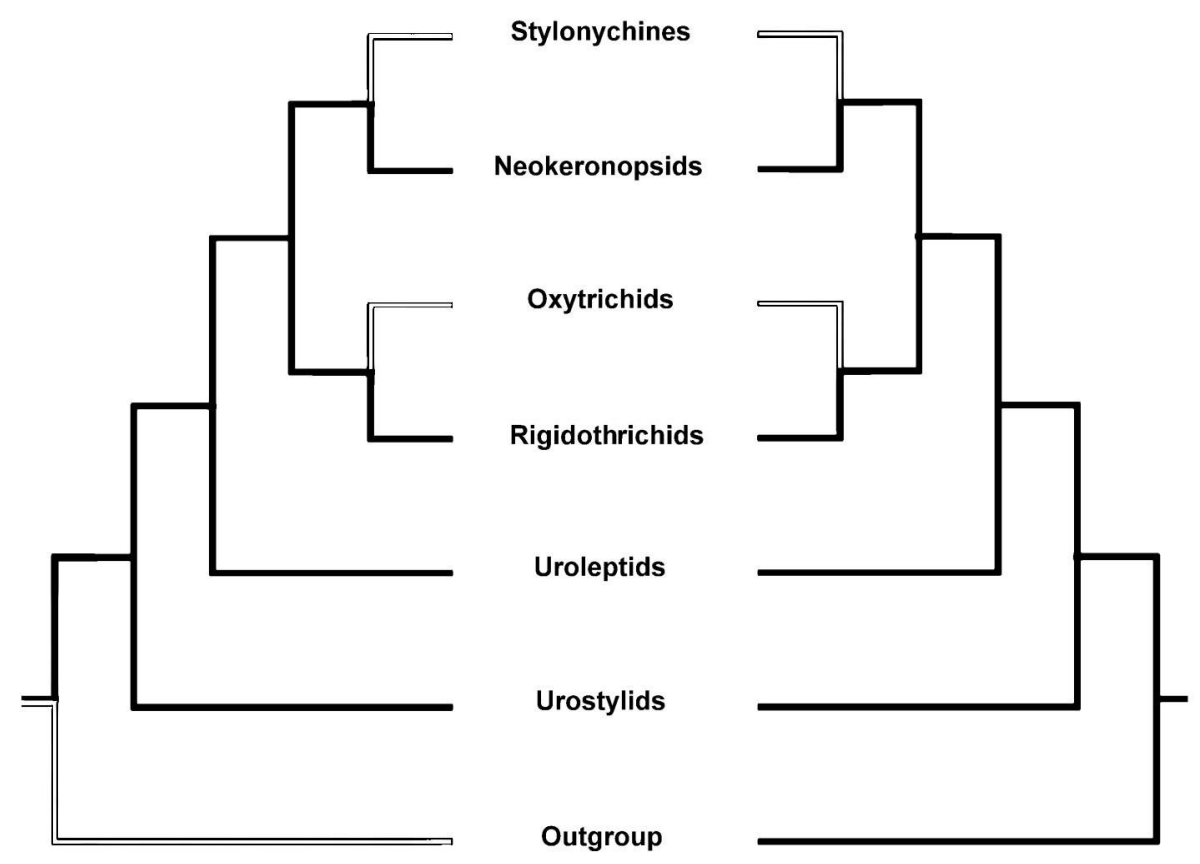

Figure 4. Trees modified from Foissner and Stoeck (2008, p. 31) showing changes of the character "presence of midventral complex" (absent $=$ white lines; present $=$ black lines), polarized with different outgroups: without midventral complex in the left tree ( 3 steps), and with midventral complex $(2$ steps $)$ in the right tree. The presence of the complex in neokeronopsids may, however, be homoplastic. See "Results and Discussion".

The midventral complex occurs in some hypotrich taxons; hence, this structure could be a trait reminiscent of an ancestor with ventral architecture similar to that of a hypotrich with a midventral complex, like a gastrocirrhid or even a discocephalid in which the cirri from 
the midventral pairs were not partially reabsorbed during late morphogenesis (see Wicklow, 1982), thus maintaining their pairwise configuration. This apparently raises the possibility that contrary to what is suggested by Foissner and Stoeck (2008), the same trend of maintaining the plesiomorphic midventral complex might have occurred in the neokeronopsids (Figure 4). However, Pattersoniella is unlikely to be sufficiently closely related to urostylids or Rigidothrix and Uroleptus (Figures 1,2), and the statistical tests rejected the null hypothesis in scenarios IV and VIII (Table 3). So, considering the position of Pattersoniella in our optimal trees (Figures 1,2), the possibility of the midventral complex in the neokeronopsids actually being a homoplasy (Foissner and Stoeck, 2008) instead of plesiomorphic is accepted in the current state of knowledge.

Finally, the tests involving trees where the global monophyly of the urostylids was enforced allowed us to reject the null hypothesis, with the exception of the SH test in scenario V; however, with a P value very close to the critical level (Table 3). These results corroborate the hypotheses that: i) Pseudoamphisiella is more closely related to discocephalids than to the core urostylids (Yi et al., 2008b); ii) Parabirojimia and Trachelostyla may be sister groups (Yi et al., 2008a); iii) Holosticha branches at the base of core Stichotrichia (Schmidt et al., 2007; Yi, et al., 2008a), and iv) discocephalids may be an intermediate taxon between urostylids and euplotids (Wicklow, 1982).

\section{The polyphyly of Oxytricha}

The large genus Oxytricha currently contains more than 50 valid species. According to Berger (1999), identification of Oxytricha species is a difficult task, due to their overall morphological similarity. Several species originally assigned to Oxytricha were relocated to other genera after detailed studies of morphology were performed (for reviews see Berger, 1999, 2001). Currently, about three fourths of the valid congeners lack investigation with modern microscopy techniques, so it is possible that the present circumscription of Oxytricha is artificial (Berger, 1999). Our tests rejected the null hypothesis for scenario IX, thus the monophyly of Oxytricha based on 18S data alone is unlikely (Table 3). The phylogenetic patterns obtained in both trees are compatible with that reported by Schmidt et al. (2007), except for Oxytricha saltans, which grouped with Gonostomum in their study.

Remarkably, Oxytricha saltans was the most distant congener (Table 5). This species has a peculiar oral apparatus bearing a flexible spur-like protrusion (Song and Wilbert, 1997) and its adoral zone of membranelles is slightly bipartite, with the crown membranelles pointy and longer than usual in this genus. Additionally, based on the morphology reported in Song and Wilbert (1997), it is possible to interpret the shape of the anterior region of the cell as that of a shortened trachelostylid frontal scutum. Furthermore, Berger (1999) emphasized that the cirral pattern in this species is not like that in typical oxytrichids. Even though Oxytricha saltans has at least one dorsomarginal kinety (Song et al., 1991; Song and Wilbert, 1997; Berger, 1999), a trait absent in urostylids (Berger, 2006), its position as sister group of Holosticha was strongly supported in our trees and the branching pattern at the base of the core Stichotrichia corroborated a report by Shin (2005). Thus, the results indicate that the reactivation of the old basionym Actinotricha saltans is suitable, but checking morphogenetic data is strongly recommended prior to adopting this convention. 
Table 5. Pairwise distance matrix of Oxytricha $18 \mathrm{~S}-\mathrm{rDNA}$ sequences from our data set (in \%).

\begin{tabular}{rlrrrrrrrrrr}
\hline & 1 & 2 & 3 & 4 & 5 & 6 & 7 & 8 & 9 & 10 \\
\hline 1 & & & & & & & & \\
2 & Oxytricha granulifera 1 & & & & & & & & & & \\
2 & Oxytricha granulifera 2 & 2.6 & & & & & & & & \\
3 & Oxytricha granulifera 3 & 0.8 & 2.5 & & & & & & & \\
4 & Oxytricha granulifera 4 & 0.2 & 2.8 & 1.0 & & & & & & \\
5 & Oxytricha granulifera 5 & 0.0 & 2.6 & 0.8 & 0.2 & & & & & \\
6 & Oxytricha longigranulosa & 3.8 & 0.0 & 2.5 & 2.8 & 2.6 & & & & \\
7 & Oxytricha elegans & 2.8 & 1.6 & 3.2 & 3.0 & 2.8 & 1.6 & & & \\
8 & Oxytricha lanceolata & 3.3 & 1.9 & 3.3 & 3.5 & 3.3 & 1.9 & 2.3 & & & \\
9 & Oxytricha ferruginea & 3.3 & 4.0 & 3.6 & 3.6 & 3.3 & 4.0 & 3.7 & 3.5 & & \\
10 & Oxytricha longa & 3.8 & 3.0 & 4.0 & 4.1 & 3.8 & 3.0 & 3.3 & 2.8 & 3.3 & \\
11 & Oxytricha saltans & 9.6 & 10.2 & 10.1 & 9.9 & 9.6 & 10.2 & 9.4 & 10.4 & 9.8 & 10.3 \\
\hline
\end{tabular}

Moreover, the results also corroborated the hypothesis of Eigner (1997) that the 18 fronto-ventral-transverse cirri pattern of oxytrichids evolved more than once. Thus, future analyses of additional sequences from other Oxytricha species and supposedly related organisms (e.g., Notohymena, Tachysoma, Urosoma, Urosomoida) are expected to improve the knowledge concerning the evolution of this group.

\section{The Halteria paradox}

One of the most controversial issues in molecular phylogeny of ciliates was the position of Halteria grandinella, traditionally classified as an oligotrich by morphologists (e.g., Kahl, 1932; Corliss, 1979; de Puytorac et al., 1994; Lynn and Small, 2002; Lynn, 2003), but placed alongside flexible body oxytrichids (viz. Oxytricha granulifera) in ribosomal molecular trees (Lynn and Sogin, 1988; Hoffman and Prescott, 1997; Bernhard et al., 2001; Snoeyenbos-West et al., 2002; Hewitt et al., 2003; Strüder-Kypke and Lynn, 2003; Foissner et al., 2004; Schmidt et al., 2007). The same case applies to the related organism Meseres corlissi (Foissner et al., 2004). Nevertheless, an $\alpha$-tubulin based tree in Snoeyenbos-West et al. (2002) has placed Halteria among choreotrichid oligotrichs.

The exact phylogenetic position of Halteria grandinella within stichorichs varied slightly in our trees according to inference criteria and had weak bootstrap support in both analyses (Figures 1,2). With the exception of the WS, all tests failed to reject the null hypotheses for scenario X (Table 3); hence the resolution of $18 \mathrm{~S}$ alone was considered insufficient to unambiguously define the position of this organism. Indeed, according to Agatha (2004), the placement of Halteria as a sister group of Oxytricha granulifera would require that several probably complex morphological features (e.g., enantiotropic divisional morphogenesis) evolved in convergence with the Oligotrichia. In our constrained trees (not shown), Halteria grandinella always branched from the base of Oligotrichia, agreeing with phylogenetic inferences based on morphology (de Puytorac et al., 1984, 1994; Petz and Foissner, 1992; Agatha, 2004; Agatha and Strüder-Kypke, 2007; Foissner et al., 2007).

\section{Monophyletic Stichotrichia?}

The null hypothesis for scenario XI was rejected by all tests except for SH; there- 
fore, the results do not support the monophyly of Stichotrichia sensu Berger (2006). Since the two optimal trees were not consensual concerning the phylogenetic pattern at the base of the ingroup, we compared them with two other scenarios (Table 3), independently reinforcing the inclusion of Holosticha spp + Oxytricha saltans and Pseudoamphisiella spp within the core Stichotrichia.

Both scenarios XII and XIII do not differ significantly from the optimal NJ tree. However, both the Tempelton and WS tests rejected the null hypothesis in scenario XIII (= scenario XII due to the position of Holosticha spp and Oxytricha saltans in the MPC). Thus, in the parsimony framework, the inclusion of Pseudoamphisiella spp in the core Stichotrichia made the constrained tree significantly longer than the optimal one (Table 3 ).

Although the two constraints are different, the $\mathrm{P}$ values from the $\mathrm{SH}$ and WSH tests for scenario XII indicate that this constrained topology is less different from the optimal NJ tree than the one from scenario XIII. Hence, the monophyly of Stichotrichia is acceptable in the parsimony analysis context when Pseudoamphisiella is considered as an external taxon. Actually, the possibility of Pseudoamphisiella being more close to discocephalids than holostichid urostylids is sustained by the morphological similarity between Pseudoamphisiella and Psammocephalus faurei in traits such as the cephalized frontal scutum and the overall developmental processes of the ciliature pattern (Wicklow, 1982; Song et al., 1997).

\section{FINAL CONSIDERATIONS}

Inconsistency among phylogenetic inferences may occur due to various causes, including differences in properties of the reconstruction methods employed (Hillis, 1987). The quality of taxon and character sampling are relevant factors that interfere in phylogenetic inferences (Bergsten, 2005). According to Berger in Foissner and Stoeck (2008), there are approximately 600 valid stichotrich species, corresponding to about 9.7 times the total of stichotrich 18S-rDNA sequences that we used in our study, albeit more than $50 \%$ of the estimated number of extant ciliates species are still unknown to science (Foissner et al., 2002). Thus, according to Berger (2006), less than $5 \%$ of the stichotrich species that probably exist have been examined in molecular phylogenies to date! Therefore, an effort to augment taxon sampling is necessary to increase the accuracy of phylogenetic estimates (Hillis, 1996, 1998; Graybeal, 1998; Ranalla et al., 1998; Bergsten, 2005). Concerning stichotrichs, this should focus on taxons that have been little sampled, such as amphisiellids, flexible-body oxytrichids, kahliellids, and spirofilids. As demonstrated by Hillis (1998), an increase in the number of characters used in phylogenetic inferences can also increase their accuracy, reaching a point where all branches in a tree are correctly estimated with 5000 nucleotides, which is about 3 times the number of characters that we used in our study.

We conclude that within the context of the data analyzed and the methodology adopted, the phylogeny of 18S-rDNA alone did not yield enough resolution to reliably estimate many of the branching patterns within stichotrichs; thus, proposal of hypotheses on evolution based on these topologies alone should be extremely cautious. In fact, some internal groups were consistently supported by the data, such as the Stylonychinae and the core urostylids, thus indicating that the $18 \mathrm{~S}$ holds potential for resolving stichotrich systematics at low taxonomic levels. Soltis et al. (1999) reached a similar conclusion studying land plants, and attributed the low resolution at higher taxonomic levels to conflicting signals at the $18 \mathrm{~S}$ variable sites and 
insufficient signals at the conserved ones. Noteworthy, the use of a single gene in phylogeny estimates may also be problematic because if its evolution differs from that of species, the trees can yield well-supported, but inaccurate topologies concerning species evolution (Doyle, 1992). Therefore, as pointed out by Bergsten (2005), the addition of different kinds of data, preferably from genes with different proprieties or evolution rates is necessary to overcome single-gene biases. The study by Snoeyenbos-West et al. (2002) demonstrated that internal transcribed spacer (ITS), and especially $\alpha$-tubulin matrices, possess higher nucleotide divergence than $18 \mathrm{~S}$ among choreotrichs, oligotrichs and stichotrichis. Hence, new studies with these markers and that include significantly larger and more homogeneous taxon sampling are expected to better address the molecular systematics of Stichotrichia.

\section{ACKNOWLEDGMENTS}

We are very thankful to Orlando da Conceição Simões for his technical support, to Alexandre Maia for collecting samples of mud from Alma River (Tocantins, Brazil), and to the reviewers for their comments and suggestions. Research supported by a doctoral fellowship provided to M.Sc. T.S. Paiva by CAPES through Programa de Pós-graduação em Zoologia, Museu Nacional, UFRJ, and by research funds from CNPq and FAPERJ.

\section{REFERENCES}

Affa'a FM, Hickey DA, Struder-Kypke M and Lynn DH (2004). Phylogenetic position of species in the genera Anoplophrya, Plagiotoma, and Nyctotheroides (Phylum Ciliophora), endosymbiotic ciliates of annelids and anurans. J. Eukaryot. Microbiol. 51: 301-306.

Agatha S (2004). A cladistic approach for the classification of oligotrichid ciliates (Ciliophora: Spirotricha). Acta Protozool. 43: 201-217.

Agatha S and Strüder-Kypke MC (2007). Phylogeny of the order Choreotrichida (Ciliophora, Spirotricha, Oligotrichea) as inferred from morphology, ultrastructure, ontogenesis, and SSrRNA gene sequences. Eur. J. Protistol. 43: 37-63.

Akaike HA (1974). A new look at the statistical model identification. IEEE Trans. Automat. Contr. 19: 716-723.

Berger H (1999). Monograph of the Oxytrichidae (Ciliophora, Hypotrichia). Monograph. Biol. 78: i-xii, 1-1080.

Berger H (2001). Catalogue of Ciliate Names 1. Verlag Helmut Berger, Salzburg.

Berger H (2003). Redefinition of Holosticha Wrzesniowski, 1877 (Ciliophora, Hypotricha). Eur. J. Protistol. 39: 373-379.

Berger H (2006). Monograph of the urostyloidea (Ciliophora, Hypotricha). Monograph. Biol. 85: i-xvi, 1-1304.

Berger H and Foissner W (1997). Cladistic relationships and generic characterization of oxytrichid hypotrichs (Protozoa, Ciliophora). Arch. Protistenkd. 148: 125-155.

Bergsten J (2005). A review of long-branch attraction. Cladistics 21: 163-193.

Bernhard D, Stechmann A, Foissner W, Ammermann D, et al. (2001). Phylogenetic relationships within the class Spirotrichea (Ciliophora) inferred from small subunit rRNA gene sequences. Mol. Phylogenet. Evol. 21: 86-92.

Borror AC (1972). Revision of the order Hypotrichida (Ciliophora, Protozoa). J. Protozool. 19: 1-23.

Borror AC (1979). Redefinition of the Urostylidae (Ciliophora, Hypotrichida) on the basis of morphogenetic characters. J. Eukaryot. Microbiol. 26: 544-550.

Bos DH and Posada D (2005). Using models of nucleotide evolution to build phylogenetic trees. Dev. Comp. Immunol. 29: 211-227.

Brinkmann H, van der Giezen M, Zhou Y, Poncelin de RG, et al. (2005). An empirical assessment of long-branch attraction artefacts in deep eukaryotic phylogenomics. Syst. Biol. 54: 743-757.

Buckley TR, Simon C, Shimodaira H and Chambers GK (2001). Evaluating hypotheses on the origin and evolution of the New Zealand alpine cicadas (Maoricicada) using multiple-comparison tests of tree topology. Mol. Biol. Evol. 18: 223-234.

Carpenter JM (1996). Uninformative bootstrapping. Cladistics 12: 177-181.

Cavalier-Smith T and Chao EE (2003). Phylogeny of choanozoa, apusozoa, and other protozoa and early eukaryote megaevolution. J. Mol. Evol. 56: 540-563. 
Corliss JO (1979). The Ciliated Protozoa. Characterization, Classification and Guide to the Literature. Pergamon Press, Oxford.

Croft KE, Dalby AB, Hogan DJ, Orr KE, et al. (2003). Macronuclear molecules encoding actins in spirotrichs. J. Mol. Evol. 56: 341-350.

Dalby AB and Prescott DM (2004). The scrambled actin I gene in Uroleptus pisces. Chromosoma 112: 247-254.

de Puytorac P, Grain J, Legendre P and Devaux J (1984). Essai d'application de l'analyse phénétique à la classification du phylum des Ciliophora (Application test of phenetic analysis to Ciliophora phylum classification). $J$. Protozool. 31: 496-507.

de Puytorac P, Grain J and Legendre P (1994). An attempt at reconstructing the phylogenetic tree of Ciliophora using parsimony methods. Eur. J. Protistol. 30: 1-17.

Deane JA, Strachan IM, Saunders GW, Hill DRA, et al. (2002). Cryptomonad evolution: Nuclear 18S rDNA phylogeny versus cell morphology and pigmentation. J. Phycol. 38: 1236-1244.

Dieckmann J (1995). An improved Protargol impregnation for ciliates yielding reproducible results. Eur. J. Protistol. 31: 328-372.

Doyle JJ (1992). Gene trees and species trees: molecular systematics as one-character taxomony. Syst. Bot. 17: 144-163.

Dragesco J and Dragesco-Kernéis (1986). Ciliés Libres de L'Afrique Intertropicale. Introduction à la Connaissance et à L'étude des Ciliés. Faune tropicale. Editions de l'Orstom, Paris, 1-559.

Eigner P (1997). Evolution of morphogenetic processes in the Orthoamphisiellidae N. Fam., Oxytrichidae, and Parakahliellidae N. fam., and their depiction using a computer method (Ciliophora, Hypotrichida). J. Eukaryot. Microbiol. 44: 1S-92S-553-573.

Eigner P (1999). Comparison of divisional morphogenesis in four morphologically different clones of the genus Gonostomum and update of the natural hypotrich system (Ciliophora, Hypotrichida). Eur. J. Protistol. 35: 34-48.

Eigner P (2001). Divisional morphogenesis in Uroleptus caudatus (Stokes, 1886), and the relationship between the Urostylidae and the Parakahliellidae, Oxytrichidae, and Orthoamphisiellidae on the basis of morphogenetic processes (Ciliophora, Hypotrichida). J. Eukaryot. Microbiol. 48: 70-79.

Eigner P and Foissner W (1994). Divisional morphogenesis in Amphisiellides illuvialis N. sp., Paramphisiella caudata (Hemberger) and Hemiamphisiella terricola Foissner, and redefinition of the amphisiellidae (Ciliophora, Hypotrichida). J. Eukaryot. Microbiol. 41: 243-261.

Eisler K and Fleury A (1995). Morphogenesis and Evolution in Ciliates. Protistological Actualities. In: Proceedings of the Second European Congress of Protistology Universite Blaise Pascal, Clermont-Ferrand, 102-127.

Farris JS (1969). A successive approximations approach to character weighting. Syst. Zool. 18: 374-385.

Farris JS (1972). Estimating phylogenetic trees from distance matrices. Am. Nat. 106: 645-668.

Farris JS (1989a). The retention index and homoplasy excess. Syst. Zool. 38: 406-407.

Farris JS (1989b). The retention index and the rescaled consistency index. Cladistics 5: 417-419.

Felsenstein J (1978). Cases in which parsimony or compatibility methods will be positively misleading. Syst. Zool. 27: 401-410.

Feng DF and Doolittle RF (1987). Progressive sequence alignment as a prerequisite to correct phylogenetic trees. $J$. Mol. Evol. 25: 351-360.

Foissner W (1989). Morphologie und Infraciliatur einiger neuer und wenig bekannter terrestrischer und limnischer Ciliaten (Protozoa: Ciliophora). Sber. Akad. Wiss. Wien 196: 173-247. Available at [http://zoology.fns.uniba.sk/ffs/ interface/00840.pdf].

Foissner W (1991). Basic light and scanning electron microscopic methods for taxonomic studies of ciliated protozoa. Eur. J. Protistol. 27: 313-330.

Foissner W and Stoeck T (2006). Rigidothrix goiseri nov. gen., nov. spec. (Rigidotrichidae nov. fam.), a new "flagship" ciliate from the Niger floodplain breaks the flexibility-dogma in the classification of stichotrichine spirotrichs (Ciliophora, Spirotrichea). Eur. J. Protistol. 42: 249-267.

Foissner W and Stoeck T (2008). Morphology, ontogenesis and molecular phylogeny of Neokeronopsis (Afrokeronopsis) aurea nov. subgen., nov. spec. (Ciliophora: Hypotricha), a New African flagship ciliate confirms the CEUU hypothesis. Acta Protozool. 47: 1-33.

Foissner W, Agatha S and Berger H (2002). Soil ciliates (Protozoa, Ciliophora) from Namibia (Southwest Africa), with emphasis on two contrasting environments, the Etosha Region and the Namib Desert. Denisia 5: 1-1459.

Foissner W, Der Staay SYMV, Van Der Staay GWM, Hackstein JHP, et al. (2004). Reconciling classical and molecular phylogenies in the stichotrichines (Ciliophora, Spirotrichea), including new sequences from some rare species. Eur. J. Protistol. 40: 265-281.

Foissner W, Müller H and Agatha S (2007). A comparative fine structural and phylogenetic analysis of resting cysts in 
oligotrich and hypotrich Spirotrichea (Ciliophora). Eur. J. Protistol. 43: 295-314.

Gascuel O (1997). BIONJ: an improved version of the NJ algorithm based on a simple model of sequence data. Mol. Biol. Evol. 14: 685-695.

Giribet G and Wheeler WC (1999). On gaps. Mol. Phylogenet. Evol. 13: 132-143.

Goloboff PA (1993). Estimating character weights during tree search. Cladistics 9: 83-91.

Goloboff PA (1997). Self-weighted optimization: tree searches and character state reconstructions under implied transformation costs. Cladistics 13: 225-245.

Goloboff PA, Carpenter JM, Arias JS and Esquivel DRM (2008). Weighting against homoplasy improves phylogenetic analysis of morphological data sets. Cladistics 24: 1-6.

Gong J, Kim SJ, Kim SY, Min GS, et al. (2007). Taxonomic redescriptions of two ciliates, Protogastrostyla pulchra n. g., n. comb. and Hemigastrostyla enigmatica (Ciliophora: Spirotrichea, Stichotrichia), with phylogenetic analyses based on $18 \mathrm{~S}$ and 28S rRNA gene sequences. J. Eukaryot. Microbiol. 54: 468-478.

Graybeal A (1998). Is it better to add taxa or characters to a difficult phylogenetic problem? Syst. Biol. 47: 9-17.

Hall BG (2004). Tune ClustalX. Available at [http://homepage.mac.com/barryghall/TuneClustalX.html]. Accessed September 18, 2008.

Hall TA (1999). BioEdit: a user-friendly biological sequence alignment editor and analysis program for Windows 95/98/ NT. Nucleic Acids Symp. 41: 95-98.

Hess PN and de Moraes Russo CA (2007). An empirical test of the midpoint rooting method. Biol. J. Linn. Soc. 92: 669-674.

Hewitt EA, Muller KM, Cannone J, Hogan DJ, et al. (2003). Phylogenetic relationships among 28 spirotrichous ciliates documented by rDNA. Mol. Phylogenet. Evol. 29: 258-267.

Hillis DM (1987). Molecular versus morphological approaches to systematics. Annu. Rev. Ecol. Syst. 18: 23-42.

Hillis DM (1996). Inferring complex phylogenies. Nature 383: 130-131.

Hillis DM (1998). Taxonomic sampling, phylogenetic accuracy, and investigator bias. Syst. Biol. 47: 3-8.

Hillis DM, Moritz C and Mable BK (1996). Molecular Systematics. Sinauer Associates, Sunderland.

Hoffman DC and Prescott DM (1997). Phylogenetic relationships among hypotrichous ciliates determined with the macronuclear gene encoding the large, catalytic subunit of DNA polymerase alpha. J. Mol. Evol. 45: 301-310.

Kahl A (1932). Urtiere oder Protozoa. I. Wimpertiere oder Ciliata (Infusoria) 3. Spirotricha.. Tierwelt Dtl. 25: 399-650.

Källersjö M, Albert VA and Farris JS (1999). Homoplasy increases phylogenetic structure. Cladistics 15: 91-93.

Kelminson K, Hewitt E, Arkind C, Kneeland P, et al. (2002). Histone H4 genes in some stichotrichous ciliates. Eur. J. Protistol. 38: 235-246.

Kishino H, Miyata T and Hasegawa M (1990). Maximum likelihood inference of protein phylogeny and the origin of chloroplasts. J. Mol. Evol. 30: 151-160.

Kitching IJ, Forey PL, Humphries CJ and Williams DJ (1998). Cladistics. The Theory and Practice of Parsimony Analysis. The Systematics Association Publication No. II. Oxford University Press, Oxford.

Kluge AG (1997a). Testability and the refutation and corroboration of Cladistic hypotheses. Cladistics 13: 81-96.

Kluge AG (1997b). Sophisticated falsification and research cycles: Consequences for differential character weighting in phylogenetic systematics. Zool. Scripta 26: 349-360.

Kluge A (2005). What is the Rationale for “'Ockham's Razor"' (a.k.a. parsimony) in Phylogenetic Inference? In: Parsimony, Phylogeny, and Genomics (Albert V, ed.). Oxford University Press, Oxdord, 15-42.

Lartillot N, Brinkmann H and Philippe H (2007). Suppression of long-branch attraction artefacts in the animal phylogeny using a site-heterogeneous model. BMC Evol. Biol. 7 (Suppl 1): S4.

Li WH (1997). Molecular Evolution. Sinauer Associates, Sunderland.

Lynn DH (2003). The Ciliate Resource Archive. Available at [http://www.uoguelph.ca/ ciliates]. Accessed September 18, 2008.

Lynn DH and Sogin ML (1988). Assessment of phylogenetic relationships among ciliated protists using partial ribosomal RNA sequences derived from reverse transcripts. Biosystems 21: 249-254.

Lynn DH and Small EB (2002). Phylum Ciliophora. In: The Illustrated Guide to the Protozoa (Lee JJ, Leedale GF and Bradbury P, eds.). 2nd edn. The Society of Protozoologists, Lawrence, 374-656.

Maddison WP and Maddison DR (2007). Mesquite: Modular System for Evolutionary Analysis. Version 2.01. Available at [http://mesquiteproject.org]. Accessed September 18, 2008.

Motulsky HJ (1999). Analyzing Data With GraphPad Prism. GraphPad Software Inc., San Diego. Available at [www. graphpad.com]. Accessed September 18, 2008.

Nei M and Kumar S (2000). Molecular Evolution and Phylogenetics. Oxford University Press, New York.

Nixon KC (1999). The Parsimony Ratchet, a new method for rapid Parsimony analysis. Cladistics 15: 407-414.

Nixon KC and Carpenter JM (1993). On outgroups. Cladistics 9: 413-426. 
Paiva TS and Silva-Neto-ID (2007). Morphology and morphogenesis of Strongylidium pseudocrassum Wang and Nie, 1935, with redefinition of Strongylidium Sterki, 1878 (Protista: Ciliophora: Stichotrichia). Zootaxa 1559: 31-57.

Petz W and Foissner W (1992). Morphology and morphogenesis of Strobilidium caudatum (Fromentel), Meseres corlissi N. Sp., Halteria grandinella (Müller), and Strombidium rehwaldi N. Sp., and a proposed phylogenetic system for Oligotrich Ciliates (Protozoa, Ciliophora). J. Eukaryot. Microbiol. 39: 159-176.

Philippe H (2000). Opinion: long branch attraction and protist phylogeny. Protist 151: 307-316.

Philippe H and Laurent J (1998). How good are deep phylogenetic trees? Curr. Opin. Genet. Dev. 8: 616-623.

Platnick NI, Coddington JA, Forster RR and Griswold CE (1991). Spinneret morphology and the phylogeny of haplogyne spiders (Araneae, Araneomorphae). Am. Mus. Novit. 3016: 1-73.

Platnick NI, Humphries CJ, Nelson GJ and Williams DM (1996). Is Farris optimization perfect? Three-taxon statements and multiple branching. Cladistics 12: 243-252.

Posada D and Crandall KA (1998). Modeltest: testing the model of DNA substitution. Bioinformatics 14: 817-818.

Prager EM and Wilson AC (1988). Ancient origin of lactalbumin from lysozyme: analysis of DNA and amino acid sequences. J. Mol. Evol. 27: 326-335.

Qiu YL, Lee J, Whitlock BA, Bernasconi-Quadroni F, et al. (2001). Was the ANITA rooting of the angiosperm phylogeny affected by long-branch attraction? Amborella, Nymphaeales, Illiciales, Trimeniaceae, and Austrobaileya. Mol. Biol. Evol. 18: 1745-1753.

Rannala B, Huelsenbeck JP, Yang Z and Nielsen R (1998). Taxon sampling and the accuracy of large phylogenies. Syst. Biol. 47: 702-710.

Rodriguez F, Oliver JL, Marin A and Medina JR (1990). The general stochastic model of nucleotide substitution. J. Theor. Biol. 142: 485-501.

Saitou N and Nei M (1987). The neighbor-joining method: a new method for reconstructing phylogenetic trees. Mol. Biol. Evol. 4: 406-425.

Sambrook J, Fritsch EF and Maniatis T (1989). Molecular Cloning: a Laboratory Manual. Cold Spring Harbor Laboratory Press, Cold Spring Harbor.

Sanderson MJ and Shaffer HB (2002). Troubleshooting molecular phylogenetic analyses. Annu. Rev. Ecol. Syst. 33: 49-72.

Sanger F, Nicklen S and Coulson AR (1977). DNA sequencing with chain-terminating inhibitors. Proc. Natl. Acad. Sci. U. S. A. 74: 5463-5467.

Schmidt SL, Bernhard D, Schlegel M and Foissner W (2007). Phylogeny of the Stichotrichia (Ciliophora; Spirotrichea) reconstructed with nuclear small subunit rRNA gene sequences: discrepancies and accordances with morphological data. J. Eukaryot. Microbiol. 54: 201-209.

Schneider H (2007). Métodos de Análise Filogenética. Um Guia Prático. Holos Editora, Ribeirão Preto.

Shao C, Song W, Yi Z, Gong J, et al. (2007). Morphogenesis of the marine spirotrichous ciliate, Trachelostyla pediculiformis (Cohn, 1866) Borror, 1972 (Ciliophora, Stichotrichia), with consideration of its phylogenetic position. Eur. J. Protistol. 43: 255-264.

Shimodaira H (1993). A model search technique based on confidence set and map of models. Proc. Inst. Statist. Math. 41: 131-147.

Shimodaira H (1998). An application of multiple comparison techniques to model selection. Ann. Inst. Stat. Math. 50: 1-13.

Shimodaira H (2005). CONSEL Program User's Guide (V0.1i). Department of Mathematical and Computing Sciences. Tokyo Institute of Technology, Tokyo.

Shimodaira H and Hasegawa M (1999). Multiple comparisons of log-likelihoods with applications to phylogenetic inference. Mol. Biol. Evol. 16: 1114-1116.

Shimodaira H and Hasegawa M (2001). CONSEL: For assessing the confidence of phylogenetic tree selection. Bioinformatics 17: 1246-1247.

Shin MK (2005). Phylogenetic Reconstruction of Hypotrichous Ciliates (Protozoa, Ciliophora, Hypotrichida). In: The 9th Russian-Korean International Symposium on Science and Technology, Novosibirsk, 225-228.

Sikes DS and Lewis PO (2001). Beta Software, Version 1. PAUPRat: PAUP implementation of the parsimony ratchet. Distributed by the Authors. Department of Ecology and Evolutionary Biology, University of Connecticut, Storrs.

Silva-Neto ID da (1994). Observations sur l' ultrastructure du cilié heterotriche Licnophora auerbachi Cohn, 1866, epibionte de l'etoile de mer. Ann. Sci. Nat. Zool. Biol. Anim. 2: 49-62.

Snoeyenbos-West OL, Salcedo T, McManus GB and Katz LA (2002). Insights into the diversity of choreotrich and oligotrich ciliates (Class: Spirotrichea) based on genealogical analyses of multiple loci. Int. J. Syst. Evol. Microbiol. 52: 1901-1913.

Snoeyenbos-West OL, Cole J, Campbell A, Coats DW, et al. (2004). Molecular phylogeny of phyllopharyngean ciliates and their group I introns. J. Eukaryot. Microbiol. 51: 441-450.

Soltis PS, Soltis DE, Wolf PG, Nickrent DL, et al. (1999). The phylogeny of land plants inferred from 18S rDNA sequences: 
pushing the limits of rDNA signal? Mol. Biol. Evol. 16: 1774-1784.

Song W and Wilbert N (1997). Morphological investigations on some free living ciliates (Protozoa, Ciliophora) from China Sea with description of a new hypotrichous genus, Hemigastrostyla nov. gen. Arch. Protistenkd. 135: 319-325.

Song W, Shin MK and Kim W (1991). Morphology and infraciliature of the ciliate Oxytricha saltans (Cohn, 1866) Kahl, 1932 (Protozoa, Ciliophora, Hypotrichida). Korean J. Syst. Zool. 7: 233-240.

Song W, Warren A, Hu X (1997) Morphology and morphogenesis of Pseudoamphisiella lacazei (Maupas, 1883) Song, 1996 with suggestion of establishment of a new family Pseudoamphisiellidae nov. fam. (Ciliophora, Hypotrichida). Arch. Protistenk. 147: 265-276.

Strüder-Kypke MC and Lynn DH (2003). Sequence analyses of the small subunit rRNA gene confirm the paraphyly of oligotrich ciliates sensu lato and support the monophyly of the subclasses Oligotrichia and Choreotrichia (Ciliophora, Spirotrichea). J. Zool. 260: 87-97.

Swofford DL (2003). PAUP* Phylogenetic Analysis Using Parsimony (* and Other Methods). Version 4. Sinauer Associates, Sunderland.

Swofford DL, Olsen GJ, Waddell PJ and Hillis DM (1996). Phylogenetic Inference. In: Molecular Systematics (Hillis DM, Moritz C and Mable BK, eds.). Sinauer Associates, Sunderland, 407-514.

Tamura K, Dudley J, Nei M and Kumar S (2007). MEGA4: Molecular evolutionary genetics analysis (MEGA) software version 4.0. Mol. Biol. Evol. 24: 1596-1599.

Templeton AR (1983). Phylogenetic inference from restriction endonuclease cleavage site maps with particular reference to the evolution of humans and apes. Evolution 37: 221-244.

Thompson JD, Gibson TJ, Plewniak F, Jeanmougin F, et al. (1997). The CLUSTAL_X windows interface: flexible strategies for multiple sequence alignment aided by quality analysis tools. Nucleic Acids Res. 25: 4876-4882.

Tuffrau M and Fleury A (1994). Classe des Hypotrichea Stein, 1859. Traité Zool. 2: 83-151.

Turner H and Zandee M (1995). The behaviour of Goloboff's tree fitness measure F. Cladistics 11: 57-72.

Wicklow BJ (1982). The Discocephalina (n. subord.): Ultrastructure, morphogenesis and evolutionary implications of a group of endemic marine interstitial hypotrichs (Ciliophora, Protozoa). Protistologica 18: 299-330.

Xia X and Xie Z (2001). DAMBE: software package for data analysis in molecular biology and evolution. J. Hered. 92: 371-373.

Yi Z, Song W, Shao C, Warren A, et al. (2008a). Phylogeny of some systematically uncertain urostyloids - Apokeronopsis, Metaurostylopsis, Thigmokeronopsis (Ciliophora, Stichotrichia) estimated with small subunit rRNA gene sequence information: Discrepancies and agreements with morphological data. Eur. J. Protistol. 44: 254-262.

Yi Z, Song W, Warren A, Roberts DM, et al. (2008b). A molecular phylogenetic investigation of Pseudoamphisiella and Parabirojimia (Protozoa, Ciliophora, Spirotrichea), two genera with ambiguous systematic positions. Eur. J. Protistol. 44: 45-53. 